\title{
FAMILY INSTITUTION UNDER SPATIOTEMPORAL AND ONTOLOGICAL ANALYSIS
}

\author{
${ }^{1}$ Anatoliy MELNYCHUK, ${ }^{2}$ Eduard SHCHEBET \\ 1,2Taras Shevchenko National University of Kyiv, Ukraine \\ 'melan97@ukr.net
}

\begin{abstract}
This article reviews geography, essence, and regional particularities of worldwide family institution researches to identify the present condition and the perspective study areas. Necessity of this research is caused by current modernizing of family researches that will promote more effective realization of Ukraine's research and development potential. There are certain scientific geographical schools studying the institution of family, each of them having somewhat different level of research development. We distinguish American, British, French, and Russian scientific schools. Ukrainian school deals with similar problems that Russian one, but less developed due to considerable lack of specialists directly involved in the research. Accordingly, these schools have different specialization, but the important fact is that in the U.S., UK, France, Germany, Japan, and more recently in Russia, studies focus on disclosing the essence of postmodern society development and its consequences for society and the institution of the family in particular. Analyzing the data we found that the main factors defining modern family transformation in Ukraine are the media, particularly the Internet and television, advertising, and education. Today's epoch is marked by overall cultivation of the personal negative qualities and values that destroys social bonds and also leads to the individualization through the atomization of people in society. This atomization of society reduces public family relationships to primitive mechanical interaction. Spatial-ontological analysis of the condition of the family institution in Ukraine gave us the opportunity for a clear separation of the 3 macro-regions: Steppe Deep Crisis Region, Central Crisis Region and Western Region with Advancing Crisis. Historical-geographical, structural, and dynamic analysis of these regions and their components helped us to reveal ontological regional differences of the family institution caused by different stages of social transformation. The main regional consequence is that the most vulnerable situation is observed in the regions with strongly established industrial (modern) society, which is nearest to the postmodern one.
\end{abstract}

Key words: institution of family, scientific researches, perspective researching areas, essence of researches, perspective social and geographical researches.

DOI: https://doi.org/10.17721/2413-7154/2016.76.38-43

UDC: 911.3

\section{ДОСЛІДЖЕННЯ ІНСТИТУТУ СІМ'Ї: ПРОСТОРОВО-ЧАСОВИЙ ТА ОНТОЛОГІЧНИЙ АНАЛІЗ}

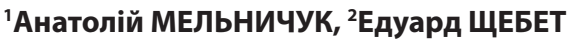 \\ 1,2Київський начіональний університет імені Тараса Шевченка, Україна \\ 'melan97@ukr.net
}

Резюме: У даній статті розглянута географія, сутність та особливості досліджень інституту сім'ї у світі задля виявлення сучасного стану і перспективних напрямків наукових досліджень. Необхідність даного дослідження пов'язана з осучасненням досліджень інституту сім'ї, що сприятиме більш ефективній реалізації науково-дослідницького потенціалу України. Можна виокремити декілька географічних наукових шкіл, які проводили дослідження інституту сім'ї, що характеризуються різними рівнями розвитку досліджень. Ми виокремлюємо американську, британську, французьку, а також російську школи. Українська школа подібна за проблематикою до російської, але гірше розвинена через суттєвий брак спеціалістів, задіяних у дослідженнях інституту сім'ї. Відповідно, спеціалізація цих шкіл різна, але важливою обставиною $\epsilon$ те, що в США, Великій Британії, Франції, Німеччині, Японії, а з останніх часів і в Росії, сучасні дослідження переходять до розкриття сутності питань становлення постмодерного суспільства і наслідків для всього суспільства та інституту сім'ї зокрема. Встановлено, що головними чинниками сучасних перетворень інституту сім'ї в Україні виступають 3Мl, зокрема Інтернет та телебачення, реклама, а також освіта. Відбувається загальна культивація негативних якостей та цінностей людини, що руйнує суспільні зв'язки, а також зумовлює індивідуалізацію шляхом атомізації людей в суспільстві. Ця атомізація суспільства мінімізує та примітивізує суспільно-сімейні зв'язки до механічної взаємодії. Просторово-онтологічний аналіз стану інституту сім'ї в Україні дав змогу чіткого виокремлення 3 макрорегіонів: степовий сильнокризовий, центральний кризовий та західний прогресуючо-кризовий. Історикогеографічний аналіз цих регіонів та їх складових разом з динамічним і структурним аналізом дав змогу встановити, що регіональні відмінності онтологічної сутності інституту сім'ї, зумовлені різною стадійністю суспільної трансформації. Головним регіональним наслідком $\epsilon$ те, що найбільш кризовий стан характерний для регіонів, де найширше встановилося індустріальне (модерне) суспільство, яке є найближчим до постмодерного.

Ключові слова: інститут сім'ї, наукові дослідження, перспективні наукові напрямки, сутність досліджень, перспективні суспільно-географічні дослідження.

DOI: https://doi.org/10.17721/2413-7154/2016.76.38-43

УдК: 911.3

(C) А. Мельничук, Е. Щебет 
Вступ. Актуальність теми. Зміни та загострення проблем в сучасному суспільстві актуалізують суспільні дослідження, які також не оминають сучасну географічну науку. При дослідженні суспільства слід зазначити фундаментальне значення дослідження інституту сім’ї. Актуальність та першочерговість дослідження інституту сім’ї обумовлена тим, що сім'я має тотожні структурні елементи суспільства і займає індивідуально-локальне положення в його ієрархії. При цьому інститут сім’ї має квазіфрактальну відповідність суспільству (відсутність абсолютизованої фрактальності обумовлена стохастичністю інституту сім’ї), тому динамічні процеси перетворення суспільства та інституту сім'ї є паралельними. Сім’я, таким чином, виступає ланкою, що перетворює сукупність людей в суспільство, бо вона є певним «міні-суспільством», де виникають суспільні відносини, що потім переносяться на оточуюче суспільство $[7,8]$.

Отже, сім'я виступає структурнофункціональною основою суспільства. Тому, для підвищення ефективності, актуальності, об'єктивності, адекватності (відповідності до реального становища) суспільно-географічних досліджень інституту сім’ї, необхідно проаналізувати сучасний стан та часові особливості дослідження інституту сім'ї в Україні та в країнах 3 провідними науковими школами 3 розкриттям найбільш актуальних аспектів досліджень в певні роки в певних країнах.

Мета i завдання дослідження. Метою виступає часово-просторовий та онтологічний аналіз досліджень інституту сім'ї та встановлення перспективних напрямків його дослідження.

Завданнями є просторово-часовий аналіз досліджень інституту сім’ї з визначенням домінуючих напрямків, виокремлення головних наукових шкіл 3 дослідження інституту сім'ї, виокремлення перспективних напрямків, характеристика трансформаційних процесів в дослідженнях інституту сім'ї, визначення місця, значення і перспективи географічних досліджень у вивченні інституту сім’ï.

Опис методики дослідження та здобутих емпіричних даних. Нами були використані дані бази наукових публікацій Google Scholar та проаналізовані в загальних рисах дослідження інституту сім’ї в Україні, а також в Росії, США, Великій Британії, Франції, Німеччині, а також частково в Китаї і Японії.

Дослідження інституту сім'ї, в цілому, почали розвиватися після 1945 року, а активні — 3 1970-х років. Але питання сім'ї піднімалося раніше, де сім'я, зазвичай, розглядалася як невід'ємна складова суспільства, як правило, в філософських роботах та релігійно-духовних ученнях. В деяких духовних ученнях i трактатах сім'я розглядалася окремо, наприклад у Іоанна Златоуста [3]. Розвиток філософіï, а також становлення психології та соціології в індустріальному суспільстві сформував новий підхід до дослідження сім’ї, де вона розглядалася як окремий об'єкт наукового пізнання.
Піонером нових досліджень інституту сім’і стали науковці США, де важливе місце посіли роботи Еріха Фромма [10] та Роберта Парка, які створили одні 3 перших грунтовних аналітичних робіт про інститут сім'ї. Хоча, в цілому, в ці роки дослідження сім’ї спиралися на аналіз статистичних та емпіричних соціологічних даних, проводилися дослідження демографічних аспектів сім’ї. Також були деякі аналітичні роботи щодо типології та

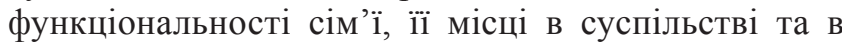
житті окремої людини. Тому перші дослідження інституту сім’ї спиралися на опис, статистичний та функціональний аналізи 3 вираженим соціологодемографічним напрямом досліджень. Цей період первинних досліджень продовжувався до 1970-х в США, Великій Британії і Франції, до 1980-х в Німеччині і до 1990-х в Росії та Україні.

Наступні дослідження стосувалися вивчення трансформаційних явищ та явищ i станів, що виникли внаслідок трансформації. Розширюється спектр досліджень. 3 1960-х років в США було актуальним дослідження сім’ї в умовах міста, завдяки бурхливому розвитку його соціології, але до 1980-х років цей напрям втратив свою актуальність, розкривши великий аспект трансформаційних процесів інституту сім'ї.

Гендерні дослідження інституту сім'і стали розвиватися в 1970-х роках в США та Великій Британії i заснували суттєво новий напрям дослідження сім'ї. Дослідження гендеру стали провідними на довгий час в США і зараз актуалізуються в Європі, особливо 3 2000-х років, але в новому ракурсі — в умовах становлення постмодерністського суспільства зі стиранням статевих відмінностей індивідуумів. Особливо велика увага дослідженню гендеру приділяється у Великій Британії. В Росії та в Україні дослідження гендерних аспектів інституту сім'ї не отримало великого поширення. Наразі актуальність гендерних досліджень інституту сім’і залишається високою для Європи, але вони втрачають свої позиції в США, а також у Великій Британії. В Свропі сучасні гендерні дослідження сім’ї суттєво приділяють увагу до економіки сім'ї, які найкраще розвинені у Франції. Важливим питанням в гендерних дослідженнях є планування сім'ї, що широко досліджувалося у Великій Британії, а наразі $€$ актуальною темою досліджень в Китаї. Сучасними провідними спеціалістами 3 цього аспекту є Ходоров Н. Дж., Роснейл С., Джеймсон Л., Ахмед С. та інші фахівці.

Останнім часом активізуються дослідження психології та здоров'я сім'ї, що є вираженням пошуку вирішення комплексу проблем суспільнодеструктивного генезису. Найбільш передовим цей напрям дослідження інституту сім’ї в США — країні 3 найбільш зруйнованим інститутом сім'ї $[1,10,11]$. Досить активно медичні дослідження розвиваються в Свропі, включаючи Україну та Росію. Актуалізується значення медичної географії при дослідженні інституту сім’і. У дослідженнях психології сім’і провідну роль грають науковці США. 
Сучасні соціологічні дослідження інституту сім'ї розкривають аспекти його трансформації, досліджують динаміку, характер змін та наслідки. Соціологічні дослідження поступово перетворюються на суспільно-філософські та суспільнопсихологічні. Статистичні та типологічні дослідження виступають допоміжними в розкритті певних питань трансформації. Провідними фахівцями в цьому аспекті є Гурко Т. А., Рагл С., Ахмед С., Дагено Д., Січчелі В., Блоссфельд Г.П., Шнайдер В. та багато інших.

Важливо зазначити, що підхід суспільних досліджень в сучасній соціології змінюється із соціоцентричного на егоцентричний, що можна вважати поглибленням і локалізацією соціологічних досліджень, що безпосередньо стосується досліджень інституту сім’ї [4].

Одночасно 3 локалізацією та індивідуалізацією досліджень інституту сім’ї, досить швидко починають розвиватися суспільно-філософські дослідження в умовах становлення постмодерного суспільства, суцільної глобалізації життя та руйнування суспільних взаємозв'язків. Рішення онтологічних та метафізичних питань інституту сім’ї та суспільства роблять цей напрямок сучасних досліджень найбільш перспективним та актуальним. Найбільший розвиток він отримав у Франції за рахунок сильної філософської школи, де особливе значення отримали ідеї та доробки екзистенціальних та постмодерністських філософів. 3 середини 2000-х років філософські дослідження стали активно розвиватися у Великій Британії і поступово поширюються в США, а також в інших державах.

Аспект глобалізації є складовою постмодерного суспільства, тому він сильно пов'язаний із суспільно-філософськими дослідженнями. Він $є$ досить новим напрямком досліджень інституту сім'ї і є поглибленням вивчення трансформаційних явищ в сучасному суспільстві. Найбільше уваги на це питання приділяється в США та в Східній Азії. Серед фахівців виокремлюються Такенака А., Блоссфельд Г. П., Січчелі В. та інші.

Хоча вивчення демографічних аспектів інституту сім’ї $€$ початковим етапом в його дослідженнях, але в новому ракурсі він розвивається в Україні, Росії, а також у Німеччині і стосується проблеми депопуляції та виродження населення i визначення місця інституту сім’ї в цих процесах. Сучасні демографічні дослідження інституту сім’і співвідносяться 3 соціологічними, гендерними i економічними аспектами.

Досить відокремленим напрямком досліджень інституту сім’ї є історико-культурний, що спирається на його вивченні у минулому. Він розвинений, в основному, в Європі. На пострадянському просторі найбільш значним дослідником є Ігор Кон, а велике методологічне значення мають напрацювання Миколи Гумільова [2], які $є$ важливими для порівняльно-географічних та порівняльно-онтологічних досліджень при вивчення особливостей та характеру трансформаційних процесів у суспільстві.
Важливо відзначити, що в сучасній науці відбуваються інтеграційні процеси, бо сьогоденні складні проблеми глобалізованого світу є багатоаспектними і вимагають комплексного вирішення, що зумовлює необхідність взаємодії між різними науковими напрямками. Це підвищує значення філософії серед наук, а також системного підходу в методології. Описані нами аспекти дослідження інституту сім’ї включають демографічний, соціо-логічний, гендерний, медичний, психологічний, історико-культурний, філософський i глобалістський, i описують певні суспільні підсистеми інституту сім'ї, окрім останніх двох інтегральних [7].

Географічна наука вирізняється інтегральним характером [9] i здатна розглядати просторові аспекти в межах певних підсистем інституту сім’ї, або в цілому, інтегруючи складові. Це є значною перевагою і важливим аспектом розкриття сутності та повноти суспільно-філософських досліджень. Також дослідження питань просторової взаємодії при вивченні сучасної глобалізації без географічних досліджень не будуть мати цілісності.

Географічні дослідження інституту сім’і розвинені недостатньо і в цілому характеризуються просторовим аналізом статистичної інформації та iii інтерпретації. Питання онтології, метафізики i трансформації інституту сім’і, як структурнофункціональної основи суспільства, в географічній науці залишаються нерозкритими.

Географія досліджень інституту сім’ї має свої особливості, де можна виокремити декілька наукових шкіл 3 різними рівнями розвитку досліджень. Отже, ми виокремлюємо американську, британську, французьку, а також російську школи. Українська школа подібна за проблематикою до російської, але гірше розвинена через суттєвий брак спеціалістів, задіяних у дослідженнях інституту сім’ї. Відповідно, спеціалізація цих шкіл різна, але важливою обставиною є те, що в США, Великій Британії, Франції, Німеччині, Японії, а 3 останніх часів і в Росії, сучасні дослідження переходять до розкриття сутності питань становлення постмодерного суспільства і наслідків для всього суспільства та інституту сім’ї зокрема.

Отже, сучасна американська школа спеціалізується на соціологічних і психологічних дослідженнях, британська - соціологічних та гендерних, французька - соціологічних i філософських, російська та українська - соціологічних та демографічних (депопуляція), німецька - соціологічних, гендерних та демографічних (депопуляція), японська - соціологічних та глобалістських, китайська - в процесі становлення, найбільше висвітлюються взаємовідносини держави та сім’ї. Провідними школами $є$ американська, британська та французька, інші суттєво відстають.

Оцінка отриманих результатів. Отже, проаналізувавши отримані дані, ми встановили онтологічні етапи розвитку досліджень інституту сім'卂, які виникли внаслідок трансформації сутності досліджень в просторово-часовому вимірі через 
переосмислення сутності і змісту об'єкта та предмета дослідження. Це стосується усіх шкіл, що досліджують інститут сім'і. Таким чином, ми виокремили наступні онтологічні етапи:

1. Соціологічно-демографічний - статистичні та емпіричні дослідження, збір даних, вивчення механізмів взаємодії, структури, функцій, існуючої проблематики, соціоцентричний підхід, дослідження моделей сім’ї, іiі типології.

2. Трансформаційно-онтологічний - дослідження різних аспектів трансформації інституту сім’ї, динамічних суспільних процесів, вивчення сутності перетворень та їх наслідків, збільшення значення гуманітарних досліджень, поглиблення досліджень

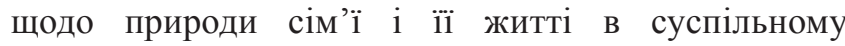
середовищі, вивчення характеру відносин, взаємозв'язків i нематеріальних складових сімейносуспільних відносин, включаючи питання сутності любові. У зв'язку 3 поглибленням досліджень встановлюється егоцентричний підхід, а 3 іншої сторони розвиваються дослідження аспектів глобалізації сім’ї, які грунтуються на розумінні природи сім’і і сімейно-суспільних відносин, що складаються в конкретному суспільстві.

3. Трансформаційно-метафізичний - новий онтологічний етап, що починає активно розвиватися, насамперед в провідних школах 3 дослідження інституту сім’і. Він спрямований на встановлення та осягнення першопричин, першооснов інституту сім'ї в нерозривному зв'язку із суспільством та Всесвітом, а також глибинної сутності його трансформації. Глобальність проблематики і системність світоустрою зумовлює необхідність іншого, більш глибокого, осмислення сутності сучасних проблем, у тому числі інституту сім’і. Актуальність цього етапу зумовлена становленням постмодерного суспільства, що створює певні загрози і проблеми [5, 6]. При цьому характер досліджень спрямований на формування цілісного бачення проблематики 3 метою осягнення абсолютного та істини. Цей етап обумовлений науковою інтеграцією та пошуком нових рішень проблем, які вже існують або тільки виникають, через глибинне дослідження природи явищ, процесів та сутності сучасних проблем.

Слід зауважити, що ті самі аспекти досліджень на різних етапах мають відмінну онтологію, що найкраще відображено в гендерному аспекті досліджень. Актуальними наразі аспектами досліджень інституту сім'ї $€$ психологічний, трансформації сім’i та суспільства, а також суспільно-філософський (включаючи глобалістський), що утворюють взаємопов'язане науковометодологічне ціле. Іншими актуальними аспектами $\epsilon$ дослідження депопуляції, регулювання чисельності населення, соціального управління сім'єю та суспільством, які доповнюють та інтегруються у вищезазначене науково-методологічне ціле. Тому спостерігається тенденція до поступового переходу соціологічних, демографічних, гендерних досліджень до суспільно-філософських через їх онтологічне переосмислення.
Інститут сім'ї в Украӥні та його дослідження. Актуальність суспільно-географічних досліджень в Україні останнім часом суттєво збільшується, що пов'язано з активними перетвореннями в суспільстві України та, в цілому, у світовому суспільстві. Активно формується глобальне суспільство. Сім'я, в свою чергу, є коміркою сучасного структурованого суспільства, елементом, що поєднує індивідуальне та суспільне. Тому, вивчення інституту сім’ї $\epsilon$ невід'ємною складовою суспільних, в тому числі суспільно-географічних, досліджень.

Ми проаналізували сучасні транформаційні процеси інституту сім’ї в Україні у розрізі суспільногеографічних досліджень. Дослідження були спрямовані на розкриття просторово-онтологічних та трансформаційно-онтологічних аспектів інституту сім’ї в Україні [12].

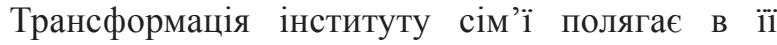
онтологічному перетворенні. Генетичними групами чинників трансформації $\epsilon$ соціально-економічні та інформаційні. Важливо відмітити, що ми встановили, що інформаційні чинники є головними в процесах трансформації інституту сім’ї. А соціально-економічні в більшій мірі відображають вплив та дію інформаційних чинників, а в меншій мірі - зміни соціальних та економічних умов життя. Наприклад, нами було встановлено, що соціальноекономічне забезпечення населення не має чіткої кореляції 3 показниками стану інституту сім'ї, так само, як і показник урбанізованості прямо не впливає на кризовість інституту сім'ї. Це доводить некоректність суспільно-статистичного аналізу для виявлення стану інституту сім’і. Дійсними чинниками перетворень $є$ трансформація ціннісних систем населення, бо на стан інституту сім'ї впливає не рівень соціально-економічного забезпечення, а економічна спрямованість пріоритетів ціннісних систем у населення. В цьому прикладі розкривається сутність трансформаційно-онтологічного підходу. Завдяки цьому виявлено, що головним соціальноекономічним чинником трансформації інституту сім’і $є$ трансформація ціннісних системи людей в суспільстві, що є втіленням інформаційного чинника в площині соціально-економічних відносин в суспільстві.

Намагання розкриття сутності просторовотрансформаційних процесів інституту сім’ї в Україні виявило, що головний чинник суспільної трансформації - інформаційний. Він полягає в суспільно-деструктивному впливі зовнішніх інформаційних джерел. Цей вплив є руйнівним для інституту сім’ї та суспільству в цілому. Деградація відбувається в умовах формування суспільства споживання, що для інституту сім’ї зумовлює поширення товарно-споживацького типу сімейних відносин, які зумовлюють збільшення поширення фактичної частки сім'єподібних утворень - форм імітованих та неконструктивних суспільносімейних відносин споживацького характеру. Було встановлено, що сучасним напрямком трансформації інституту сім’ї в сучасній Україні $\epsilon$ сексуалізація іiі сутності, що виступає основою 
чуттєвого споживання в суспільно-сімейних відносинах.

Отже, розкриття сутності трансформаційних процесів інституту сім’і в Україні виявило, що головними джерелами цих перетворень виступають 3MI та реклама, Інтернет та телебачення, а також освіта. Використання певних технологій соціального управління, у тому числі технології маніпуляції свідомості та психосоціального контролю суспільства, використання технологій «вікон Овертону», дезінформація, спонукання до прояву негативних якостей, де негативні образи наповнюються позитивним змістом, тощо. В цьому ракурсі йде загальна культивація негативних якостей та цінностей людини, що руйнує суспільні зв'язки, а також зумовлює індивідуалізацію шляхом атомізації людей в суспільстві. Ця атомізація суспільства мінімізує та примітивізує суспільносімейні зв'язки до механічної взаємодії. При цьому, розконсолідація, що призводить до ціннісної дезорієнтації, підвищує ефективність реклами та пропаганди. Ці перетворення підвищують контроль та управління населення засобами зовнішніх інформаційних джерел.

Більш глибоке розкриття сучасної сутності трансформації інституту сім’ї в Україні розкриває процеси загальноцивілізаційної, глобальної суспільної трансформації, що виражається переходом 3 премодерну через модерн в постмодерн. В цьому відношенні, посилення впливу зовнішніх джерел інформації та глобалізація світового простору $є$ важливим елементом становлення епохи постмодерну. Тому, сучасні процеси трансформації суспільства та інституту сім'ї в Україні зумовлюються, головним чином, становленням певних елементів постмодерного суспільства.

Просторово-онтологічний аналіз стану інституту сім’ї дав змогу чіткого виокремлення 3 макрорегіонів: степового сильнокризового, центрального кризового та західного прогресуючокризового. Історико-географічний аналіз цих регіонів та їх складових разом 3 динамічним і структурним дав змогу встановити, що регіональні відмінності онтологічної сутності інституту сім’ї зумовлені різною стадійністю суспільної трансформації. Головним регіональним наслідком є те, що найбільш кризовий стан характерний для регіонів, де найширше встановилося індустріальне (модерне) суспільство, яке є найближчим до постмодерного. Перетворення інституту сім’ї в постмодерні передбачає його ліквідацію, що є кінцевим етапом поглиблення суспільно-сімейної кризи у світі та в Україні зокрема.

Слід відмітити, що із загальносуспільною трансформацією, відбувається зміна статусу сім’ї в суспільстві, як наслідок. Просторово цей процес $€$ нерівномірним, але односпрямованим. В Україні, таким чином, найбільшого поширення отримала дітоцентристська сім'я, а патріархальна, позиції якої були найсильнішими в сільській місцевості, а отже в найбільш премодерному регіоні з сильними традиціями - в Західній Україні, відходить в минуле. Найбільш поширюваний тип сім’ї наразі демократичний. Він є найбільш лібералізованим, атомізованим, що робить його слабозв'язаним. Демократичний тип сім’” $є$ уособленням товарноспоживацьких відносин. Він найбільше поширений у великих містах, які $є$ найбільш модерновими. Разом 3 цим поширюються девіантні типи сімей, суттєве поширення отримує проміскуїтетні відносини, внаслідок сексуалізації сутності сім’ї. Це свідчить про широке поширення сім'єподібних відносин і виражає деградацію суспільства, його розконсолідацію та примітивізацію. Дана тенденція зумовлює посилення фізичного та духовного виродження суспільства.

Зазначене поширення сім'єподібних відносин зазначається зменшенням авторитету, значення та важливості сім’ї в житті суспільства та окремої особи. Це відповідає тенденції становлення постмодерну в основі якої є деструкція основних суспільних інститутів, особливо сім’ї. Також цей процес супроводжується поступовим зменшенням функціональності сім’ї.

Поширення властивостей i якостей постмодерну в українському суспільстві у відношенні до інституту сім’ї зумовлює збільшення рівня його кризовості. Тенденція незмінна та негативна. Важливо відмітити, що найбільш стрімко інститут

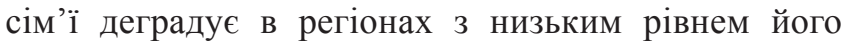
кризовості. Це стосується Західної України. Цей процес стирає регіональні відміни в напрямку розпаду інституту сім’ї в Україні. Тут добре виражається дія інформаційного чинника трансформації, що гомогенізує суспільство, впливаючи на всі регіони, в прагненні створення достатньо керованого суспільства споживання. Данна гомогенізація є продуктом суцільної деградації суспільства, в якому відбувається поступова втрата ознак суспільної системи, його спрощення та руйнування.

Отже, виявлення першопричин трансформаційних процесів інституту сім'“і актуалізує необхідність дослідження і вирішення суспільнофілософських питань. Тому в даному дослідженні ми в загальних рисах торкнулися трансформаційнометафізичного аспекту досліджень задля кращого розуміння сутності сучасної суспільно-сімейної кризи. Слід нагадати, що передові наукові школи розглядають та актуалізують питання інституту сім’і в ракурсі суспільно-філософських досліджень.

Тому для подальших досліджень та розробки заходів щодо гармонізації розвитку інституту сім’і в Україні $€$ велика потреба в комплексних просторово-онтологічних, трансформаційноонтологічних та трансформаційно-метафізичних дослідженнях, особливо щодо сутності та впливу глобальних суспільно-трансформаційних процесів в ракурсі формування та становлення постмодерного суспільства.

Висновки. Сучасні дослідження інституту сім’і, через його онтологічне переосмислення в нових суспільно-цивілізаційних умовах (становлення постмодерного суспільства), суттєво 
трансформуються в напрямку взаємодії різних наукових аспектів дослідження для вирішення комплексних суспільно-філософських проблем людства, зазначаючи системність та глобальність світового простору. У зв'язку з науковою інтеграцією, посилюється значення суспільно-географічних досліджень, особливо щодо розробки та просторовосутнісного аналізу онтологічних та метафізичних аспектів дослідження інституту сім’ї.
У контексті вивчення сучасної трансформації інституту сім’ї в Україні важливими є дослідження інформаційного простору держави та його вплив на суспільно-сімейні перетворення та процеси. Також важливим аспектом є просторова оцінка кризовості інституту сім’ї та інших суспільних інститутів 3 урахуванням світової глобалізації, інформатизації та становлення постмодерного суспільства.

\section{References:}

1. Alëšina Û.E. Cikl razvitiâ sem'i: issledovanie problemy [Cycle of family development: study of the problem]. Vestnik MGU, Seriâ 14. Psihologiâ [Bulletin of Moscow State University. Series 14 Psychology], 1987, N. 12, pp. 28-65. (In Russian).

2. Gumilëv L.N. Etnogenez i biosfera Zemli [Ethnogenesis and Earth`s biosphere], Leningrad: Gidrometeoizdat, 1990, 459 p. (In Russian)

3. Zlatoust Ioann. O hristianskom brake i ob obâzannostâh muža i ženy: Učenie Sv. Ioanna Zlatousta [About the Christian marriage and the responsibilities of husband and wife: doctrine of St John Chrysostom], Moscow, 2010, 56 p. (In Russian).

4. Karceva L. V. Model' sem'i v usloviâh transformacii rossijskogo obŝestva [The model of family in conditions of Russian society transition]. Sociologičeskie issledovaniâ [Sociological Studies], 2003. No. 7. pp. 92-100. (In Russian).

5. Luk'ânec V., Sobol' O. Gorizonty gumanitarii: problema postčelovečeskogo buduŝego [The horizons of humanities: problem of post-human future]. Fundamental'nì problemi filosofii osviti [Fundamentals of education philosophy], 2006, pp. 145-164. (In Russian).

6. Ratnikov V. P. Postmodernizm: istoki, stanovlenie, suŝnost' [Postmodernism: origins, development, essence]. Obŝestvo i filosofiâ [Society and philosophy], 2002, \#4, pp. 120-132. (In Russian).

7. Surmin U.P. Teoriâ sistem i sistemnogo analiza: Učebnoe posobie. [Theory of system and systems analysis: Training manual] - Kiev: MAUP, 2003 - 368 p. (In Russian)

8. Tišin A.I., Ėgemberdiev T.M. Fraktal'nost' čeloveka [Fraktality a human] // Fraktaly i cikly razvitiâ sistem. Materialy V Vserossijskogo postoânno dejstvuûsego naučnogo seminara «Samoorganizaciâ ustojčivyh celostnostej v prirode i obŝestve»[Electronic resource] - Access mode: http://sins.xaoc.ru/pdf/articles/ articles_r017.pdf. (In Russian).

9. Topčîev O.G. Osnovi suspil'noï geografiï: Navčal'nij posibnik [Fundamentals of human geography: Training manual], Odesa, 2001, 560 p. (In Ukrainian).

10. Fromm È. Iskusstvo lûbit'. Issledovanie prirody lûbvi: per. s ang. L.A. Černyšovoj [The Art of Loving. Study of the nature of love: translation from English], Moscow, 1990, 37 p. (In Russian).

11. Fukuâma F. Doverie: social'naâ dobrodeâtel' $i$ put' $k$ procvetaniû [Trust: the social virtue and a way to prosperity], Moscow, 2004, 732 p. (In Russian).

12. Ŝ ebet E.İ. Transformaciâ ìnstitutu sìm 'ïv Ukraïnì: sutnist'suspill'no-geografičnih doslìdžen' [Transformation of the family institution in Ukraine: the essence of human-geographical researches], course work, Kyiv, 2016, $48 \mathrm{p}$. (In Ukrainian). 